\title{
Prawne aspekty wygaszenia trwałego zarządu a zarząd ustawowy Lasów Państwowych
}

1. Instytucja trwałego zarządu występuje w różnych aktach prawnych ${ }^{1}$. Może ona oznaczać „formę prawną władania nieruchomością przez jednostkę organizacyjną" (art. 43 u.g.n.). Natomiast wygaszanie trwałego zarządu jest terminem języka prawniczego stosowanego w orzecznictwie ${ }^{2}$. Chodzi w istocie o wydanie decyzji o wygaśnięciu tego zarządu na wniosek albo z urzędu (art. 46 i 46a u.g.n.).

W obowiązujących przepisach występuje również zarząd, którego prawodawca nie określił mianem trwałego, a został on ustanowiony w drodze usta$w^{3}$ na rzecz jednostki organizacyjnej nieposiadającej osobowości prawnej (np. zarząd sprawowany przez jednostki Państwowego Gospodarstwa Leśnego

* Uniwersytet im. Adama Mickiewicza w Poznaniu.

${ }^{1}$ Na przykład art. 34 i 36 ustawy z 19 października 1991 r. o gospodarowaniu nieruchomościami rolnymi Skarbu Państwa (t.j. Dz. U. z 2020 r., poz. 2243; dalej: u.g.n.r.S.P.); ustawa z 10 kwietnia 2003 r. o szczególnych zasadach przygotowania i realizacji inwestycji w zakresie dróg publicznych (t.j. Dz.U. z 2020 r., poz. 1363); art. 43 ust. 1 ustawy z 21 sierpnia 1997 r. o gospodarce nieruchomościami (t.j. Dz. U. z 2020 r., poz. 1990 r., dalej: u.g.n.).

2 Wyrok NSA z 29 kwietnia 2011 r., I OSK 1016/10, Legalis. NSA wskazuje w uzasadnieniu: „Ustawa o lasach nie mówi nic o wygaszaniu tej formy zarządu, co sugeruje autor skargi kasacyjnej. [...] Również powoływane przez niego przepisy innych aktów prawnych nie wprowadzają takiego rozwiązania, z którego miałoby wynikać, że zarząd Lasów Państwowych winien być wygaszony w postępowaniu lokalizacyjnym, zezwalającym na realizację inwestycji drogowej (powiatowej). Jedynie trwały zarząd, regulowany przepisami ustawy o gospodarce nieruchomościami, będący prawną formą gospodarowania mieniem przez jednostkę organizacyjną, który ustanawia właściwy organ mocą decyzji, podlega wygaszeniu także w drodze decyzji, o czym stanowi art. 46 i następne ustawy o gospodarce nieruchomościami”.

${ }^{3}$ Na potrzeby dalszych rozważań zarząd ten będzie określany jako zarząd ustawowy. 
Lasy Państwowe, zwany niekiedy zarządem leśnym ${ }^{4}$ ). Zarówno w literaturze, jak i orzecznictwie można zatem spotkać poglądy wskazujące na podobieństwo zarządu trwałego i zarządu ustawowego, np. takie, że zarząd leśny jest podtypem trwałego zarządu ${ }^{5}$, z czym nie można jednak się zgodzić. Obecnie w orzecznictwie Naczelnego Sądu Administracyjnego ${ }^{6}$ podkreśla się ich odrębność. W praktyce stosowania prawa problem sprawia zwłaszcza stwierdzenie, czy zarząd powstały przed wejściem w życie ustawy o lasach przekształcił się w trwały zarząd na podstawie art. 199 ust. 2 u.g.n. i wcześniej obowiązujących przepisów ustawy o gospodarce gruntami i wywłaszczaniu nieruchomości ${ }^{7}$. Z wątpliwościami tymi związana jest kwestia relacji poszczególnych aktów prawnych, w tym ustawy o lasach i ustawy o gospodarce nieruchomościami.

Tematyka zawarta w tytule artykułu nie doczekała się dotąd odrębnego opracowania. Wątki trwałego zarządu i zarządu ustawowego były poruszane w monografiach ${ }^{8}$, a także w analizach ustawy o gospodarce nieruchomościami ${ }^{9}$, problematyki nieruchomości Zasobu Własności Rolnej Skarbu Państwa ${ }^{10}$ czy obrotu lasami Skarbu Państwa pozostającymi w zarządzie Lasów Państwowych ${ }^{11}$. Za podjęciem tej tematyki przemawiają zwłaszcza względy praktyczne. Regulacje dotyczące wygaśnięcia trwałego zarządu w odniesieniu do nieruchomości znajdujących się obecnie w zarządzie Lasów Państwowych budzą bowiem wątpliwości interpretacyjne. W obrocie prawnym wciąż obowiązują decyzje ustanawiające zarząd na tych nieruchomościach wydane jeszcze w poprzednim stanie prawnym, tj. przed wejściem w życie ustawy o lasach i ustawy o gospodarce nieruchomościami. Jednocześnie w orzecznictwie trudności sprawia ustalenie,

${ }^{4}$ Art. 4 ustawy z 28 września 1991 r. o lasach (t.j. Dz. U. z 2020 r., poz. 1463).

5 Szerzej: A. Chełchowski, Trwały zarząd nieruchomościami publicznymi, Warszawa 2010, rozdz. III, § 2, Legalis.

${ }^{6}$ Wyrok NSA z 29 kwietnia 2011 r., I OSK 1016/10, Legalis; wyrok NSA z 21 kwietnia 2020 r., I OSK 4121/18, LEX.

7 W szczególności ustawa z 29 kwietnia 1985 r. o gospodarce gruntami i wywłaszczaniu nieruchomości (Dz. U. Nr 30, poz. 127, dalej: u.g.g.w.n.).

${ }^{8}$ A. Chełchowski, Trwaty zarząd...; K. Leśkiewicz, Prawne aspekty zarządzania lasami Skarbu Państwa, Lublin 2019.

9 P. Czechowski (red.), Ustawa o gospodarce nieruchomościami. Komentarz, Warszawa 2015, LEX; por. R. Pessel, Nieruchomości Skarbu Państwa, Warszawa 2010, s. 81 i n.; J. Szachułowicz, M. Krassowska, A. Łukaszewska, Gospodarka nieruchomościami. Komentarz, Warszawa 2003, s. 14 in.

${ }^{10}$ P. Litwiniuk, Ewolucja rozwiazań normatywnych w zakresie gospodarowania nieruchomościami rolnymi Skarbu Państwa, „Studia Iurdica Agraria” 2017, t. XV, s. 277 i n.

${ }^{11}$ B. Jeżyńska, Z cywilnoprawnych zagadnień sprzedaży lasów przez osobę fizyczna, „Rejent” 1993, nr 8, s. 50; J. Bieluk, Ograniczenia w obrocie lasami w świetle prawa polskiego i unijnego, w: P. Litwiniuk (red.), Integracja europejska jako determinanta polityki wiejskiej. Aspekty prawne, Warszawa 2017, s. 323 i n.; M.H. Ziemblicki, Uwarunkowania prawne nadzoru nad lasami niestanowiącymi własności Skarbu Państwa, „Białostockie Studia Prawnicze” 2015, z. 18, s. 297 i n. 
czy i jak doprowadzić do wygaśnięcia zarządu powstałego we wspomnianym okresie (przed wejściem w życie ustawy o lasach) w sytuacji istnienia zarządu Lasów Państwowych.

Celem rozważań jest więc ustalenie, czy, a jeśli tak, to w jaki sposób możliwe jest wygaszenie zarządu powstałego w czasie obowiązywania ustawy o gospodarce gruntami i wywłaszczaniu nieruchomości ${ }^{12} \mathrm{~W}$ odniesieniu do nieruchomości objętych obecnie zarządem Lasów Państwowych. Przedstawiona zatem zostanie instytucja zarządu trwałego i zarządu Lasów Państwowych na tle prawa własności, a następnie dokonana analiza rozwiązań dotyczących wygaszania trwałego zarządu.

2. Instytucja trwałego zarządu nie jest nowa. Niektórzy autorzy podkreślają, że oddanie nieruchomości w trwały zarząd nie było uregulowane w poprzednio obowiązujących przepisach ${ }^{13}$. Zasady gospodarowania gruntami zgodnie $z$ art. 1 ust. 2 u.g.g.w.n. nie obejmowały gruntów zabudowanych, wchodzących w skład gospodarstw rolnych oraz związanych z państwowym gospodarstwem leśnym i położonych na obszarach przeznaczonych w planach zagospodarowania przestrzennego wyłącznie na cele gospodarki rolnej i leśnej. Na podstawie tego aktu grunty stanowiące własność Skarbu Państwa mogły być oddawane odpłatnie w zarząd państwowym jednostkom organizacyjnym nieposiadającym osobowości prawnej, z zastrzeżeniem ust. 4a, a grunty stanowiące własność gminy - komunalnym jednostkom organizacyjnym nieposiadającym osobowości prawnej (art. 4 ust. 4 u.g.g.w.n.).

Z kolei w $§ 5$ rozporządzenia Rady Ministrów z 16 września 1985 r. w sprawie szczegółowych zasad i trybu oddawania w zarząd oraz użytkowanie nieruchomości państwowych, przekazywania tych nieruchomości między państwowymi jednostkami organizacyjnymi i dokonywania rozliczeń z tego tytułu ${ }^{14}$, wydanym w oparciu o art. 46 i 47 wymienionej ustawy, wskazano, że wymogiem prawnym oddania nieruchomości w zarząd lub użytkowanie była decyzja terenowego organu administracji państwowej wydana na wniosek zainteresowanej państwowej jednostki organizacyjnej lub organizacji społecznej. Przekazanie nieruchomości między państwowymi jednostkami organizacyjnymi następowało na podstawie pisemnej umowy zawartej po uzyskaniu zezwolenia

12 Ustawa z 29 września 1990 r. o zmianie ustawy o gospodarce gruntami i wywłaszczaniu nieruchomości (Dz. U. Nr 79, poz. 464 ze zm.).

13 J. Jaworski, A. Prusaczyk, A. Tułodziecki, M. Wolanin, Ustawa o gospodarce nieruchomościami. Komentarz, Warszawa 2019, Legalis.

14 Rozporządzenie Rady Ministrów z 16 września 1985 r. w sprawie szczegółowych zasad i trybu oddawania w zarząd oraz użytkowanie nieruchomości państwowych, przekazywania tych nieruchomości między państwowymi jednostkami organizacyjnymi i dokonywania rozliczeń z tego tytułu (Dz. U. Nr 47, poz. 240). 
terenowego organu administracji państwowej w formie protokołu zdawczo-odbiorczego, a więc w formie pisemnej. Rozporządzenie to stanowiło w $\S 10$, że decyzja o wygaśnięciu zarządu lub użytkowania miała być wydawana w oparciu o art. 42 lub 41 u.g.g.w.r.

3. Na podstawie ustawy o gospodarce nieruchomościami stan prawny w zakresie zarządu uległ zmianie. Jak wskazuje się w literaturze i orzecznictwie, trwały zarząd nie jest prawem rzeczowym ani formą umowy uprawniającej do władania nieruchomością o charakterze cywilnoprawnym, lecz publicznoprawną formą władania nieruchomością przez określoną jednostkę organizacyjną ${ }^{15}$. W trwały zarząd może być oddana nieruchomość będąca własnością lub będąca w wieczystym użytkowaniu podmiotu oddającego ją w trwały zarząd. Nieruchomość będąca własnością Skarbu Państwa (lub będąca w wieczystym użytkowaniu Skarbu Państwa) może być oddana w trwały zarząd państwowej jednostce organizacyjnej, a nieruchomość będąca własnością jednostki samorządu terytorialnego (lub będąca w użytkowaniu wieczystym tej jednostki) może być oddana w trwały zarząd samorządowej jednostce organizacyjnej utworzonej przez tę jednostkę samorządu terytorialnego ${ }^{16}$. Chodzi zasadniczo o realizację celu prowadzenia działalności należącej do zakresu działania danej jednostki na nieruchomości objętej trwałym zarządem.

Trwały zarząd jest instytucją uregulowaną w różnych aktach prawnych. Według ustawy o gospodarce nieruchomościami (art. 43 ust. 1 i 2) trwały zarząd jest formą prawną władania nieruchomością przez jednostkę organizacyjną. Jednostka organizacyjna ma prawo, z zastrzeżeniem wyjątków wskazanych w ustawie, korzystania z nieruchomości oddanej w trwały zarząd, a w szczególności do: korzystania z nieruchomości w celu prowadzenia działalności należącej do zakresu jej działania; zabudowy, odbudowy, rozbudowy, nadbudowy, przebudowy, remontu lub rozbiórki obiektu budowlanego na nieruchomości, zgodnie z przepisami prawa budowlanego, za zgodą organu nadzorującego; oddania nieruchomości lub jej części w najem, dzierżawę albo użyczenie na czas nie dłuższy niż czas, na który został ustanowiony trwały zarząd, z równoczesnym zawiadomieniem właściwego organu i organu nadzorującego, jeżeli umowa jest zawierana na czas oznaczony do 3 lat, albo za zgodą tych organów, jeżeli umowa jest zawierana na czas oznaczony dłuższy niż 3 lata lub czas nieoznaczony, jednak na okres nie dłuższy niż czas, na który został ustanowiony trwały zarząd; zgoda jest wymagana również w przypadku, gdy po umowie zawartej

${ }^{15}$ Wyrok WSA w Warszawie z 3 czerwca 2004 r., I SA 2372/02, Legalis.

${ }^{16}$ M. Wolanin, w: J. Jaworski, A. Prusaczyk, A. Tułodziecki, M. Wolanin, Ustawa o gospodarce nieruchomościami..., art. 43, Legalis. 
na czas oznaczony strony zawierają kolejne umowy, których przedmiotem jest ta sama nieruchomość.

Z kolei według ustawy o gospodarowaniu nieruchomościami rolnymi Skarbu Państwa (art. 34 ust. 1) nieruchomości wchodzące w skład Zasobu Własności Rolnej Skarbu Państwa mogą być przekazane państwowym jednostkom organizacyjnym nieposiadającym osobowości prawnej w trwały zarząd, przy czym regulacja ta ma zastosowanie odpowiednio do jednostek organizacyjnych samorządu województwa realizujących zadania związane z melioracjami wodnymi, jako zadania z zakresu administracji rządowej, w zakresie niezbędnym do wykonywania tych zadań. Przekazanie w trwały zarząd może mieć postać decyzji dyrektora generalnego Krajowego Ośrodka Wsparcia Rolnictwa (KOWR) albo umowy zawartej za jego zgodą między jednostkami wskazanymi w art. 34 (art. 35 u.g.n.r.S.P.).

Natomiast zgodnie z ustawą o lasach nieruchomości przeznaczone na drogi krajowe, stanowiące własność Skarbu Państwa, zarządzane przez Lasy Państwowe, stają się nieodpłatnie, z mocy prawa, przedmiotem trwałego zarządu ustanowionego na rzecz Generalnej Dyrekcji Dróg Krajowych i Autostrad z dniem, w którym decyzja o ustaleniu lokalizacji drogi krajowej stała się ostateczna (art. 38a ust. 1). Podstawą ustanowienia trwałego zarządu jest decyzja starosty. Te same zasady dotyczą odpowiednio nieruchomości objętej decyzją o: zezwoleniu na realizację inwestycji w zakresie lotniska użytku publicznego w rozumieniu przepisów ustawy z 12 lutego 2009 r. o szczególnych zasadach przygotowania i realizacji inwestycji $\mathrm{w}$ zakresie lotnisk użytku publicznego ${ }^{17}$ wydaną na rzecz podmiotu, o którym mowa w art. 28 ust. 1 tej ustawy, z tym że ustanowienie trwałego zarządu stwierdza wojewoda w drodze decyzji; pozwoleniu na realizację inwestycji w rozumieniu przepisów ustawy z 8 lipca $2010 \mathrm{r}$. o szczególnych zasadach przygotowania do realizacji inwestycji w zakresie budowli przeciwpowodziowych ${ }^{18}$ wydaną na rzecz podmiotu, o którym mowa w art. 2 pkt 2 tej ustawy, z tym że ustanowienie trwałego zarządu stwierdza wojewoda w drodze decyzji. Trwały zarząd (nieodpłatny) sprawuje także zarząd drogi w zakresie gruntów w pasie drogowym (art. 22 ust. 1) na podstawie ustawy o drogach publicznych ${ }^{19}$.

Te przykładowe regulacje świadczą o zróżnicowaniu zakresu i stopniu szczegółowości rozwiązań prawnych dotyczących trwałego zarządu. Ich wspólnym mianownikiem może być to, że dotyczą wydzielonego ustawowo, decyzją lub

17 Ustawa z 12 lutego 2009 r. o szczególnych zasadach przygotowania i realizacji inwestycji w zakresie lotnisk użytku publicznego (t.j. Dz. U. z 2018 r., poz. 1380).

18 Ustawa z 8 lipca 2010 r. o szczególnych zasadach przygotowania do realizacji inwestycji w zakresie budowli przeciwpowodziowych (t.j. Dz. U. z 2021 r., poz. 484).

19 Ustawa z 21 marca 1985 r. o drogach publicznych (t.j. Dz. U. z 2020 r., poz. 470). 
umową, fragmentu sfery uprawnień właścicielskich. Z tych względów warto dokonać porównania trwałego zarządu z prawem własności.

4. Trwały zarząd tylko pozornie jest podobny do prawa własności. Jak wskazywał Walerian Pańko, własność ,rodziła się i przetrwała wraz z rozwojem społeczeństwa, stanowiąc fundamentalną, a także integralną część całego systemu prawa" ${ }^{20}$. Rolą prawa miało być ,takie ukształtowanie systemu zarządzania gospodarką, stworzenia takiego modelu własności mienia państwowego, powierzanego podmiotom gospodarującym, by owe interesy tych podmiotów składały się niejako na wspólny interes gospodarki narodowej i państwa"21.

Edward Gniewek wskazuje natomiast, że w obowiązującym stanie prawnym, choć własność prywatna jest docelowym modelem stosunków własnościowych w kształtowanym współcześnie ustroju gospodarczym państwa, to „[w]olno w szczególności wyróżniać własność państwową (własność Skarbu Państwa i innych państwowych osób prawnych) czy też własność samorządową (własność gmin, powiatów i województw oraz innych samorządowych osób prawnych). W żadnym razie nie chodzi tu o intensyfikację ochrony takiej własności. Trzeba natomiast akcentować raczej szczególne obowiązki i specjalne zasady zarządzania własnością publiczną"22. Podział ten nawiązuje do własności przysługującej państwu, która może być źródłem innych węższych uprawnień do mienia jednostek, którym powierzono ich wykonywanie na rzecz Skarbu Państwa.

W istocie to model własności państwowej oraz fragmentaryzacja i dekompozycja uprawnień właścicielskich w okresie PRL, a także w obowiązującym stanie prawnym stały się źródłem ukształtowania przez prawodawcę sposobów i tytułów posiadania mienia Skarbu Państwa przez jednostki organizacyjne zarządzające nim (zarówno posiadające osobowość prawną - głównie w okresie PRL, jak i jej nieposiadające).

Już w okresie międzywojennym i powojennym były podejmowane próby „zorganizowania własności państwowej przy użyciu instrumentarium zbliżonego do trwałego zarządu"23. Obowiązujący wówczas art. 128 Kodeksu cywilnego ${ }^{24}$ stanowił wszak, że socjalistyczna własność ogólnonarodowa (państwowa) przysługiwała niepodzielnie państwu, a państwowe osoby prawne wykonywały we własnym imieniu uprawnienia wynikające z własności mienia Skarbu Państwa,

${ }^{20}$ W. Pańko, O prawie własności i jego współczesnych funkcjach, Katowice 2016, s. 14.

${ }^{21}$ Ibidem, s. 31.

22 E. Gniewek, Kodeks cywilny. Księga druga. Własność i inne prawa rzeczowe. Komentarz, Kraków 2001, LEX.

${ }^{23}$ Szerzej: A. Chełchowski, Trwaty zarzad ..., rozdz. II, § 1.

${ }^{24}$ Ustawa z 23 kwietnia 1964 r. Kodeks cywilny (Dz. U. Nr 16, poz. 93; dalej: k.c.). 
którym zarządzały ${ }^{25}$. Warto wspomnieć, że na tle tego przepisu została wydana uchwała Sądu Najwyższego, mająca moc zasady prawnej, w której wskazano: „Z chwilą wejścia w życie ustawy z dnia 31 stycznia 1989 r. o zmianie ustawy - Kodeks cywilny (Dz. U. Nr 3, poz. 11) zniesiona została zasada, że jedynie Skarbowi Państwa może przysługiwać prawo własności mienia państwowego, w wyniku czego państwowe osoby prawne uzyskały zdolność prawną w zakresie nabywania składników majątkowych na własność" 26.

Właściciel może wykonywać prawo własności w granicach ujętych $\mathrm{w}$ art. $140 \mathrm{k.c.}, \mathrm{tj}$. w granicach określonych przez ustawy i zasady współżycia społecznego może (z wyłączeniem innych osób) korzystać z rzeczy zgodnie ze społeczno-gospodarczym przeznaczeniem swego prawa, w szczególności pobierać pożytki i inne dochody z rzeczy ${ }^{27}$. W tych samych granicach może rozporządzać rzeczą. Zgodnie ze stanowiskiem wyrażonym przez Sąd Najwyższy art. 140 k.c. wskazuje nie tylko na pozytywny zakres prawa podmiotowego własności (ius utendi, ius fruendi, ius disponendi), jako najszerszego prawa podmiotowego bezwzględnego, ale także na granice własności dotyczące zachowań właściciela, których prawo własności nie obejmuje. Jeśli określone zachowania właściciela są sprzeczne z ustawą, ze społeczno-gospodarczym przeznaczeniem własności i z zasadami współżycia społecznego, to nie mogą się one mieścić w treści prawa własności ${ }^{28}$.

Z kolei przez zasady współżycia społecznego rozumie się ,zasady etycznego postępowania wyprowadzane $\mathrm{w}$ naszym społeczeństwie $\mathrm{z}$ chrześcijańskiego systemu wartości, którymi każdy członek społeczeństwa powinien kierować się w postępowaniu wobec innych" ${ }^{29}$. Różnie natomiast rozumie się klauzulę społeczno-gospodarczego przeznaczenia prawa. Dla jednych straciła ona znaczenie, gdyż była właściwa dla poprzedniego ustroju, dla innych - zachowała swoją przydatność, ponieważ wyznacza charakterystyczną cechę własności jako kompleksu praw i obowiązków i pomaga sądom w rozpatrywaniu roszczeń windykacyjnych, negatoryjnych czy odszkodowawczych ${ }^{30}$.

Ponieważ jednak własność nie jest nieograniczonym prawem, konieczne jest wyważenie interesu właściciela i innych osób. Szczególnym ograniczeniom pod-

${ }^{25}$ A. Chełchowski, Trwaty zarząd..., rozdział I, § 2, pkt II.

${ }^{26}$ Uchwała SN 7 sędziów - zasada prawna z 18 czerwca 1991 r., III CZP 38/91, LEX.

27 Wyrok TK z 20 kwietnia 1993 r., P 6/92, OTK 1993/1/ 8. Trybunał Konstytucyjny stwierdził, że prawo własności traktowane jest w systemie prawnym jako prawo podmiotowe o najszerszej treści w porównaniu z innymi prawami. Nie jest jednak prawem absolutnym (ius infinitum); por. uchwała SN z 16 lipca 1980 r., III CZP 45/80, LEX.

28 Wyrok SN z 12 lipca 2012 r., I CSK 676/11, LEX.

29 J. Gudowski (red.), Kodeks cywilny. Komentarz, t. 2: Własność i inne prawa rzeczowe, Warszawa 2016, LEX.

${ }^{30}$ Ibidem. 
lega prawo własności Skarbu Państwa i prawo własności jednostek samorządu terytorialnego. Sposób gospodarowania jest ściśle regulowany przepisami prawa administracyjnego materialnego, np. ustawy o gospodarce nieruchomościami czy ustawy o lasach ${ }^{31}$.

Na tym tle wyraźnie widać, że trwały zarząd objęty choćby tylko wspomnianymi wyżej regulacjami uwzględnia w zasadzie wszystkie uprawnienia właściciela, tj. ius utendi, ius fruendi $\mathrm{i}$ ius disponendi, poza prawem do rozporządzania nieruchomością. Ustalenie tego sprawia, że granice między prawem własności a trwałym zarządem nie są odległe, choć wyraźne.

5. W systemie prawa obowiązują rozwiązania kształtujące także ustawowy zarząd. W szczególności zarząd taki został określony w art. 4 ustawy o lasach i oddaje sposób wykonywania prawa własności w stosunku do nieruchomości leśnych Skarbu Państwa. W ujęciu historycznym zarząd leśny powiązany był z jednością władzy i własności państwowej. Oprócz gospodarki leśnej elementem kształtującym i wpływającym na wykonywanie prawa własności w odniesieniu do mienia objętego zarządem Państwowego Gospodarstwa Leśnego Lasy Państwowe jest gospodarowanie nieruchomościami leśnymi oraz ruchomościami Skarbu Państwa ${ }^{32}$. Ustawą, która reguluje sposób wykonywania prawa własności w odniesieniu do nieruchomości leśnych, jest ustawa o lasach. Własność Skarbu Państwa w odniesieniu do nieruchomości leśnych objętych zarządem Państwowego Gospodarstwa Leśnego Lasy Państwowe oraz sposób wykonywania i korzystania z tego prawa są szczegółowo uregulowane, trzeba jednak stwierdzić, że zakres uprawnień zarządcy sięga daleko, poza granice prawne trwałego zarządu, wskazane w przywołanych wyżej aktach prawnych. W szczególności zarząd ustawowy sprawowany jest przez jednostkę organizacyjną nieposiadającą osobowości prawnej i obejmuje realizację trwale zrównoważonej gospodarki leśnej, gospodarkę mieniem, a w tym prawo do zbywania i nabywania nieruchomości.

Innym przykładem ustawowego zarządu są rozwiązania dotyczące Krajowego Ośrodka Wsparcia Rolnictwa (państwowej osoby prawnej), obejmujące mienie wchodzące do Zasobu Własności Rolnej Skarbu Państwa, i zadania określone zwłaszcza w ustawie o Krajowym Ośrodku Wsparcia Rolnictwa (art. 9) ${ }^{33}$ oraz ustawie o gospodarowaniu nieruchomościami rolnymi Skarbu Państwa. Warto odnotować, że stosunki prawne łączące Skarb Państwa, „zarządcę” (dawniej Agencję Własności Rolnej Skarbu Państwa, obecnie Agencję Nieruchomości Rolnych) mienia wchodzącego w skład Zasobu Własności Rolnej Skarbu Pań-

31 Wyrok TK z 25 maja 1999 r., SK 9/98, OTK 1999/4/78.

${ }^{32}$ K. Leśkiewicz, Prawne aspekty zarządzania lasami ..., s. 214 i n. i powołana tam literatura.

${ }^{33}$ Ustawa z 10 lutego 2017 r. o Krajowym Ośrodku Wsparcia Rolnictwa (t.j. Dz. U. z 2020 r., poz. 481). 
stwa oraz osoby trzecie były określane (nie zawsze zgodnie w literaturze) jako stosunek powierniczy ${ }^{34}$. W obowiązującym stanie prawnym kontynuowany jest kierunek realizacji przez KOWR polityki państwa, w tym celów publicznych i wykonywania prawa własności na podstawie ustawy o gospodarowaniu nieruchomościami rolnymi Skarbu Państwa. Zmieniającym się tłem pozostaje wspomniana polityka.

Trzeba podkreślić, że wspólną płaszczyzną zarządu ustawowego i trwałego są ustawowo określone cele, do jakich nieruchomości objęte tymi instytucjami mogą być wykorzystane. Chodzi o realizację ustawowych zadań jednostek zarządzających. Ta wspólna cecha przybliża niewątpliwie te instytucje do siebie, choć nadal występują między nimi istotne różnice, np. przesłanki i sposób wygaśnięcia (wygaszenia) zarządu. O ile w odniesieniu do zarządu trwałego właściwe przepisy - odpowiednie do źródła powstania trwałego zarządu - regulują wymogi i przesłanki tego procesu (np. ustawa o gospodarce nieruchomościami i wcześniejsze akty prawne), o tyle w odniesieniu do zarządu ustawowego wymagane jest uchwalenie ustawy uchylającej obowiązujące rozwiązania prawne.

6. Mimo jasnych, jak się wydaje, podobieństw i różnic zarządu ustawowego i trwałego wyznaczenie granic jurydycznych między tymi instytucjami sprawia niekiedy trudności. Problemy interpretacyjne pojawiają się w kontekście relacji poszczególnych aktów prawnych, w tym ustawy o lasach i ustawy o gospodarce nieruchomościami lub ustawy o gospodarce nieruchomościami rolnymi Skarbu Państwa w połączeniu z niedoskonałością lub brakiem regulacji intertemporalnych.

Zgodnie $\mathrm{z}$ art. 75 ust. 1 ustawy o lasach dotychczasowe jednostki organizacyjne, tj. wcześniej istniejące okręgowe zarządy lasów państwowych, utworzone na podstawie art. 6 ust. 2 lit. a ustawy z 20 grudnia 1949 r. o państwowym gospodarstwie leśnym ${ }^{35}$, stały się regionalnymi dyrekcjami Lasów Państwowych, a nadleśnictwa - nadleśnictwami w rozumieniu ustawy. Według zaś art. 75 ust. 2 ustawy o lasach mienie okręgowych zarządów lasów państwowych stało się odpowiednio mieniem zarządzanym przez regionalne dyrekcje Lasów Państwowych i nadleśnictwa. Uregulowanie to jednak nie rozwiało, a wręcz wywołało i nadal wywołuje wątpliwości, jak należy traktować zarząd powstały na podstawie przepisów ustawy o gospodarce gruntami i wywłaszczaniu nieruchomości ${ }^{36}$ po wejściu w życie ustawy o lasach. Ponadto według art. 199 ust. 2 u.g.n. zarząd

${ }^{34}$ M. Możdżeń-Marcinkowski, Agencja Nieruchomości Rolnych, Kraków 2003, s. 87.

${ }_{35}$ Ustawa z 20 grudnia 1949 r. o państwowym gospodarstwie leśnym (Dz. U. Nr 63, poz. 494 z późn. zm.).

${ }^{36}$ Por. ustawa z 29 września 1990 r. o zmianie ustawy o gospodarce gruntami i wywłaszczaniu nieruchomości (Dz. U. poz. 464 z późn. zm.). 
nieruchomości stanowiących własność Skarbu Państwa oraz własność gminy, sprawowany $\mathrm{w}$ dniu wejścia $\mathrm{w}$ życie niniejszej ustawy przez jednostki organizacyjne, przekształca się z tym dniem w trwały zarząd tych nieruchomości.

Kwestią sporną w orzecznictwie było to, czy wyrażenie ,jednostki organizacyjne" dotyczy również osób prawnych, czy tylko jednostek bez osobowości prawnej ${ }^{37}$. NSA wskazał w wyroku z 4 czerwca $2007 \mathrm{r}^{38}$, że przez jednostkę organizacyjną należy rozumieć państwową lub samorządową jednostkę organizacyjną nieposiadającą osobowości prawnej, ale także posiadającą osobowość prawną, gdyż definicji ustawowej nie można odnosić do przepisów przejściowych.

Z kolei w wyroku z 12 kwietnia 2012 r. ${ }^{39}$ NSA przyjął przeciwnie, tj. że art. 199 ust. 2 u.g.n. powinien być rozumiany jako dotyczący tylko jednostek organizacyjnych nieposiadających osobowości prawnej. Jak dowodził, ustalenie to odpowiada definicji legalnej zawartej w art. 4 pkt 10 wymienionej ustawy, a także przepisom regulującym instytucję trwałego zarządu, z których wynika, że prawo to może przysługiwać jedynie podmiotom nieposiadającym osobowości prawnej (np. art. 47 ust. 1, art. 48 ust. 1, art. 49a pkt 1, w których mowa jest o organie nadzorującym jednostkę). NSA podkreślił, że ustalenia zawarte w wyroku potwierdza też art. 51 i następne u.g.n., w których rozróżnia się sposoby wyposażania w nieruchomości niezbędne do działalności: $\mathrm{z}$ jednej strony państwowych osób prawnych (otrzymują grunt na własność lub w użytkowanie wieczyste), z drugiej strony państwowych jednostek organizacyjnych (otrzymują nieruchomość w trwały zarząd). W doktrynie opowiedziano się za tym drugim stanowiskiem $\mathrm{NSA}^{40}$.

7. W obrocie prawnym pojawiają się kontrowersje dotyczące podstaw prawnych wygaśnięcia zarządu powstałego w poprzednim stanie prawnym, a także inne problemy prawne, np. gdy nieruchomości, których dotyczy trwały zarząd powstały w czasie obowiązywania ustawy o gospodarce gruntami i wywłaszczaniu nieruchomości, zostają przeznaczone na cele publiczne. W klasycznych przypadkach, tj. gdy trwały zarząd powstał na podstawie obowiązujących przepisów, stosuje się szczególne zasady wygaszania trwałego zarządu wskazane w odpowiednich ustawach. W przypadku zarządu powstałego jeszcze w czasie obowiązywania ustawy o gospodarce gruntami i wywłaszczania nieruchomości, przed wejściem w życie ustawy o lasach, prowadzi to do trudności w ustaleniu

37 Wyrok NSA z 4 czerwca 2007 r., I OSK 964/06, Legalis; wyrok NSA z 12 kwietnia 2012 r., I OSK 496/11, Legalis.

${ }^{38}$ Wyrok NSA z 4 czerwca 2007 r., I OSK 964/06.

39 Wyrok NSA z 12 kwietnia 2012 r., I OSK 496/11.

${ }^{40}$ M. Wolanin, w: J. Jaworski, A. Prusaczyk, A. Tułodziecki, M. Wolanin, Ustawa o gospodarce nieruchomościami..., art. 199. 
regulacji mających zastosowanie właśnie do wygaszania trwałego zarządu, spowodowanych problemami z ustaleniem właściwego stanu prawnego, albo skutków niejasnych przepisów przejściowych ustawy o lasach oraz ustawy o gospodarce nieruchomościami.

Kontrowersje pojawiają się również, gdy na nieruchomości Skarbu Państwa znajdującej się w zarządzie ustawowym jednostek Lasów Państwowych utrzymuje się „prawo zarządu" ustanowione decyzją administracyjną jeszcze w czasie obowiązywania ustawy o gospodarce gruntami i wywłaszczaniu nieruchomości. Do tego odnosi się orzecznictwo, aczkolwiek niejednolicie, gdyż niektóre stanowiska dopuszczają wygaszenie zarządu w trybie ustawy o gospodarce nieruchomościami tak jak trwałego zarządu, a inne nie.

Na przykład Naczelny Sąd Administracyjny w wyroku z 29 kwietnia 2011 r. ${ }^{41}$ stwierdził, że zarząd, o którym mowa w ustawie o lasach, nie jest tożsamy z trwałym zarządem, o którym mowa w ustawie o gospodarce nieruchomościami. Racją jest bowiem, że „, $[\mathrm{u}]$ stawa o lasach nie mówi nic o wygaszaniu tej formy zarządu, będącej administrowaniem mieniem leśnym Skarbu Państwa. Również inne akty prawne nie wprowadzają takiego rozwiązania, z którego miałoby wynikać, że zarząd Lasów Państwowych winien być wygaszony w postępowaniu lokalizacyjnym, zezwalającym na realizację inwestycji drogowej (powiatowej). Jedynie trwały zarząd, uregulowany przepisami ustawy o gospodarce nieruchomościami, będący prawną formą gospodarowania mieniem przez jednostkę organizacyjną, który ustanawia właściwy organ mocą decyzji, podlega wygaszeniu także w drodze decyzji, o czym stanowi art. 46 i następne ustawy z dnia 21 sierpnia 1997 r. o gospodarce nieruchomościami”. Przedstawiony pogląd Naczelnego Sądu Administracyjnego nie jest jednak jedyny.

W niedawnym wyroku z 21 kwietnia 2020 r. ${ }^{42}$ NSA uznał bowiem, że zarządu regulowanego ustawą o lasach nie należy utożsamiać $\mathrm{z}$ instytucją trwałego zarządu regulowaną w ustawie o gospodarce nieruchomościami, a „[z]arząd, do którego odnosi się przepis art. 46 ust. 2 u.g.n., należy odczytywać przez pryzmat poprzedzających go bezpośrednio norm, które regulują oddawanie nieruchomości w trwały zarząd - jako formę prawną władania nieruchomością przez jednostkę organizacyjną". Naczelny Sąd Administracyjny uznał także, iż przepisy ustawy o lasach, choć nie przewidują wygaśnięcia zarządu, to nie odsyłają do stosowania $\mathrm{w}$ tym zakresie norm zawartych w ustawie o gospodarce nieruchomościami. Dostrzegając autonomię aktu prawnego, jakim jest ustawa o lasach, NSA podkreślił: „Zarząd jako ustawowa forma władania gruntami państwowymi sprawowana jest m.in. poprzez prowadze-

\footnotetext{
${ }^{41}$ Wyrok NSA z 29 kwietnia 2011 r., I OSK 1016/10, Legalis.

42 Wyrok NSA z 21 kwietnia 2020 r., I OSK 4121/18, LEX.
} 
nie gospodarki leśnej, gospodarowanie gruntami i innymi nieruchomościami oraz ruchomościami związanymi z gospodarką leśną (art. 4 ust. 2 ustawy o lasach)". NSA nie wyjaśnił jednak do końca motywów prezentowanego stanowiska. Jako kwestię otwartą pozostawił to, jakie normy poprzedzające bezpośrednio art. 46 ust. 2 u.g.n. miałyby znaleźć zastosowanie do wygaszenia zarządu powstałego przed wejściem w życie ustawy o lasach. Dla porządku należy wskazać, że w badanym przez NSA stanie faktycznym wojewoda decyzją z 1974 r. orzekł o przekazaniu przez Naczelnika Miasta Powiatu na rzecz Okręgowego Zarządu Lasów Państwowych nieruchomości rolnej z przeznaczeniem do zagospodarowania leśnego, a nadleśnictwo przejęło przedmiotową nieruchomość na podstawie protokołu zdawczo-odbiorczego z 1974 r. Własność Skarbu Państwa, zarząd nadleśnictwa zostały ujawnione w księdze wieczystej. Wnioskiem z 2016 r. Polski Związek Działkowców wystąpił o wydanie decyzji o wygaśnięciu trwałego zarządu nadleśnictwa w odniesieniu do przedmiotowej nieruchomości na podstawie art. 46 ust. 2 pkt $1 \mathrm{w}$ zw. z art. 199 ust. 2 u.g.n., a starosta decyzją odmówił stwierdzenia wygaśnięcia trwałego zarządu w trybie art. 46 ust. 2 pkt 1 w zw. z art. 199 ust. 2 u.g.n. Wojewoda utrzymał w mocy zaskarżoną decyzję starosty, do której złożona została skarga do sądu administracyjnego, który z kolei wskazał, że sporny zarząd nadleśnictwa miał swoje źródło w decyzji, na podstawie której doszło do przekazania na rzecz Okręgowego Zarządu Lasów Państwowych nieruchomości, w trybie rozporządzenia Rady Ministrów z 22 listopada 1968 r. w sprawie przekazywania nieruchomości rolnych i niektórych innych nieruchomości położonych na terenie gromad pomiędzy jednostkami gospodarki uspołecznionej ${ }^{43}$, tj. w „użytkowanie” ( $\$ 2$ ust. 1 tego rozporządzenia), które nie stanowiło ograniczonego prawa rzeczowego w rozumieniu art. $252 \mathrm{i}$ następne k.c. ani innego ograniczonego prawa rzeczowego, lecz specyficzną formę władania gruntem państwowym przez państwową jednostkę organizacyjną ${ }^{44}$.

W postępowaniu objętym wspomnianym rozstrzygnięciem NSA słusznie wskazano, że użyty w art. 2 u.g.n. zwrot „nie narusza” nie musi oznaczać, że chodzi o nadanie przepisom ustawy o lasach charakteru lex specialis, a przepisom ustawy o gospodarce nieruchomościami charakteru lex generalis. Dla

${ }^{43}$ Rozporządzenie Rady Ministrów z 22 listopada 1968 r. w sprawie przekazywania nieruchomości rolnych i niektórych innych nieruchomości położonych na terenie gromad pomiędzy jednostkami gospodarki uspołecznionej (Dz. U. z 1969 r., Nr 1, poz. 1 z późn. zm.).

${ }^{44}$ Wspomniane rozporządzenie zostało uchylone $\mathrm{z}$ dniem 7 maja $1986 \mathrm{r}$. przez $\S 16$ rozporządzenia Rady Ministrów z 7 kwietnia 1986 r. w sprawie zasad i trybu przekazywania między jednostkami gospodarki uspołecznionej państwowych nieruchomości rolnych i leśnych oraz niektórych innych nieruchomości położonych na obszarach przeznaczonych w planach zagospodarowania przestrzennego na cele gospodarki rolniczej i leśnej, a także właściwości organów w tych sprawach (Dz. U. Nr 17, poz. 90). 
przypomnienia, według art. 2 u.g.n. nie narusza ona innych ustaw w zakresie dotyczącym gospodarki nieruchomościami, w tym ustawy o lasach. Wspomniana regulacja określa zatem relacje między przepisami ustawy o gospodarce nieruchomościami a innymi ustawami. Użyte w art. 2 ustawy o gospodarce nieruchomościami sformułowanie „W szczególności” oznacza, że katalog wskazanych w tym przepisie ustaw jest otwarty.

W piśmiennictwie wskazuje się, że przepis art. 2, w przypadku zbiegu kolizyjnego norm ustawy o gospodarce nieruchomościami i innych ustaw, daje pierwszeństwo tym ,innym ustawom” regulującym gospodarkę nieruchomościami w ramach ich zakresu przedmiotowego ${ }^{45}$. Niezasadne jest ograniczenie zakresu pojęcia spraw podlegających przepisom o gospodarce nieruchomościami tylko do czynności cywilnoprawnych znajdujących materialnoprawną podstawę $\mathrm{w}$ ustawie o gospodarce nieruchomościami ${ }^{46}$. Należy zgodzić się z poglądem, że przepisy ustawy o gospodarce nieruchomościami mają charakter uzupełniający wobec innych ustaw dotyczących gospodarowania nieruchomościami, szczególnie nieruchomościami Skarbu Państwa i jednostek samorządu terytorialnego $0^{47}$. Warto też odnotować stanowisko wyrażone w orzecznictwie, że mimo różnego brzmienia przepisów art. 1 ust. 2 u.g.g.w.n. i art. 1 u.g.n. nie ma powodów, by za nieuzasadniony należało uznać pogląd o wyłączeniu funkcjonowania ustawy o gospodarce nieruchomościami w stosunku do nieruchomości objętych pojęciem lasu zgodnie z art. 3 ustawy o lasach ${ }^{48}$. Powyższe ustalenia nie dają jednak jasnej odpowiedzi, w jaki sposób i na podstawie jakich przepisów miałoby dojść do wygaszenia zarządu powstałego przed wejściem w życie ustawy o lasach, skoro obecnie jest sprawowany przez jednostki Lasów Państwowych zarząd ustawowy na podstawie ustawy o lasach.

Biorąc pod uwagę wskazówki NSA, że zarząd, do którego odnosi się przepis art. 46 ust. 2 u.g.n., należy odczytywać przez pryzmat poprzedzających go bezpośrednio norm, które regulują oddawanie nieruchomości w trwały zarząd, wyrażone w wyroku z 21 kwietnia 2020 r., nie jest jasne, czy NSA chodziło o art. 35 ust. 1 i 2 u.g.g.w.n. Zgodnie z art. 35 ust. 1 tego aktu wygaśnięcie zarządu następuje z upływem okresu, na który został ustanowiony, a w razie jego ustanowienia na okres nieoznaczony $-\mathrm{w}$ terminie ustalonym $\mathrm{w}$ decyzji o wygaśnięciu zarządu, umożliwiającym zlikwidowanie działalności zarządcy na tej nieruchomości. Z kolei art. 35 ust. 2 stanowi, że rejonowy organ rządowej

${ }^{45}$ P. Czechowski (red.), Ustawa o gospodarce nieruchomościami...

${ }^{46}$ Wyrok NSA z 5 sierpnia 2015 r., I FSK 4079/14, LEX nr 1783697.

${ }^{47}$ Tak: M. Wolanin, w: J. Jaworski, A. Prusaczyk, A. Tułodziecki, M. Wolanin, Ustawa o gospodarce nieruchomościami ..., art. 2 i powołane tam orzecznictwo Sądu Najwyższego.

48 Wyrok WSA w Lublinie z 6 lipca 2004 r., II SA/Lu 1270/03, Legalis. 
administracji ogólnej w odniesieniu do gruntów stanowiących własność Skarbu Państwa, a zarząd gminy w odniesieniu do gruntów stanowiących własność gminy może orzec o wygaśnięciu zarządu ustanowionego na okres nieoznaczony lub przed upływem okresu, na który został ustanowiony: 1) w razie stwierdzenia, że nieruchomość jest w całości lub w części zbędna zarządcy bądź jest wykorzystywana niezgodnie z jej przeznaczeniem; 2) jeżeli sposób korzystania z nieruchomości pogarsza stan środowiska w stopniu zagrażającym życiu, zdrowiu lub mieniu; 3) jeżeli w planie zagospodarowania przestrzennego zajdą zmiany, które nie pozwalają na dalsze wykorzystywanie nieruchomości lub jej części w dotychczasowy sposób, a zarządca nie wyraził zgody na zmianę sposobu wykorzystywania nieruchomości.

Gdyby przyjąć, że na warunkach wskazanych w art. 35 u.g.g.w.n. miałoby nastąpić wygaszenie zarządu, nie sposób pominąć tego, że dawniej NSA orzekł, iż organ administracji nie może wydać na podstawie art. 35 ust. 1 i 2 u.g.g.w.n. decyzji o wygaśnięciu zarządu, o jakim mowa w art. 4 ust. 1 ustawy o lasach, do czasu wyłączenia nieruchomości będącej lasem z produkcji leśnej w trybie i na zasadach określonych w ustawie z 3 lutego 1995 r. o ochronie gruntów rolnych i leśnych ${ }^{49}$.

Co więcej, według NSA nie jest też możliwe wygaśnięcie prawa użytkowania, skoro ,[k]ategoryczna treść art. 2 ust. 8 ustawy z dnia 29 września 1990 r. o zmianie ustawy o gospodarce gruntami i wywłaszczaniu nieruchomości (Dz. U. Nr 79, poz. 464) ${ }^{50}$ nie daje podstaw do sięgania do innych przepisów, w szczególności przepisów k.c. Z jednej strony brak jest klauzuli »w sprawach nieuregulowanych «, z drugiej - wykorzystaniu klauzuli zawartej w art. 7 ustawy z 1985 r. o gospodarce gruntami i wywłaszczaniu nieruchomości stoi na przeszkodzie okoliczność, że ustanie zarządu w formie jego wygaśnięcia jest wyczerpująco unormowane w art. 35 ustawy z 1985 r. Jeśli do użytkowania, o którym mowa w art. 2 ust. 4 i 5 ustawy z 29 września 1990 r., stosuje się wprost art. 35 ustawy z 1985 r., a w przepisie tym w sposób szczególny, a zarazem wyczerpujący uregulowano ustanie zarządu, to nie ma podstaw prawnych zezwalających na sięgnięcie do art. 246 k.c." ${ }^{51}$

Gdyby zatem przyjąć za właściwe zastosowanie kierunku interpretacji postulowanej przez NSA w powyższych rozstrzygnięciach, należałoby dopuścić wygaśnięcie decyzji w okolicznościach objętych art. 35 u.g.g.w.n., ale wtedy pojawiłby się problem, czy zarząd ustawowy leśny nadal się utrzymuje.

49 Wyrok NSA z 13 stycznia 2015 r., I OSK 1543/14, LEX.

50 Ustawa ta utraciła moc na podstawie art. 241 pkt 2 u.g.n., tj. z dniem wejścia jej w życie, czyli 1 stycznia $1998 \mathrm{r}$.

51 Wyrok NSA (do 2003.12.31) w Gdańsku z 22 grudnia 1998 r., II SA/Gd 296/97, LEX. 
8. Wywody zawarte w przywołanym orzecznictwie NSA kierują rozważania w stronę ustawy z 29 września 1990 r. o zmianie ustawy o gospodarce gruntami i wywłaszczaniu nieruchomości ${ }^{52}$. Zgodnie z art. 2 ust. 1 tego aktu grunty stanowiące własność Skarbu Państwa lub własność gminy (związku międzygminnego), $\mathrm{z}$ wyłączeniem gruntów Państwowego Funduszu Ziemi, będące w dniu 5 grudnia 1990 r. w zarządzie państwowych osób prawnych innych niż Skarb Państwa, stają się z tym dniem z mocy prawa przedmiotem użytkowania wieczystego. Nie narusza to praw osób trzecich. Uprawnienia państwowych gospodarstw rolnych do będących w dniu 5 grudnia 1990 r. w ich zarządzie gruntów stanowiących własność Skarbu Państwa reguluje odrębna ustawa. Z kolei według art. 2 ust. 4 tej ustawy grunty stanowiące własność Skarbu Państwa lub własność gminy (związku międzygminnego), będące w dniu 5 grudnia 1990 r. w użytkowaniu osób prawnych lub jednostek organizacyjnych nieposiadających osobowości prawnej, pozostają nadal w użytkowaniu tych osób i jednostek (na mocy art. 2 ust. 8 do użytkowania stosuje się przepisy dotyczące zarządu). Należy też uwzględnić art. 4 ustawy zmieniającej, wedle którego grunty Skarbu Państwa pozostające w zarządzie jednostek nieposiadających osobowości prawnej nadal pozostają w ich zarządzie.

Trzeba podkreślić, że uwłaszczeniu w trybie art. 2 ust. 1 noweli z 29 września 1990 r., a co za tym idzie - w trybie art. 200 u.g.n. podlegały tylko te grunty leśne, które są związane z państwowymi gospodarstwami leśnymi, jeżeli w dniu 5 grudnia 1990 r., będąc w zarządzie państwowej osoby prawnej, w planach zagospodarowania przestrzennego nie były przeznaczone wyłącznie na cele gospodarki leśnej ${ }^{53}$. Do tego należy dodać, że w 1990 r. obowiązywała wspomniana ustawa o państwowym gospodarstwie leśnym z 1949 r., a od 1 stycznia 1992 r. - ustawa o lasach. Artykuł 200 u.g.n. nie ma zastosowania do gruntów leśnych, a przepis ustawy, która weszła w życie 1 stycznia 1998 r. w art. 2 stanowił, że ustawa nie narusza innych ustaw w zakresie dotyczącym gospodarki nieruchomościami, w szczególności ustawy o lasach.

Zgodnie $\mathrm{z}$ art. 6 ust. 2 ustawy o państwowym gospodarstwie leśnym administrację państwowego gospodarstwa leśnego w zakresie czynności gospodarczo-leśnych sprawowały przedsiębiorstwa lasów państwowych, które posiadały osobowość prawną, a w pozostałym zakresie wskazanym w art. 6 ust. 2 lit. b wymienionego aktu - inne przedsiębiorstwa ${ }^{54}$. Jeśli więc przepisu przejściowego (art. 199 ust. 2 u.g.g.) nie stosuje się do osób prawnych (zgodnie z orzeczeniem NSA z 12 kwietnia 2012 r.), to likwidację instytucji zarządu przysługującego

52 Ustawa z 29 września 1990 r. o zmianie ustawy o gospodarce gruntami i wywłaszczaniu nieruchomości (Dz. U. Nr 79, poz. 464).

${ }^{53}$ Wyrok WSA siedziba w Warszawie z 15 marca 2011 r., I SA/Wa 1787/10, Legalis.

${ }^{54}$ Chodzi o przedsiębiorstwa utworzone przez ministra leśnictwa na podstawie i w trybie dekretu z 3 stycznia 1947 r. o tworzeniu przedsiębiorstw państwowych (Dz. U. Nr 8, poz. 42). 
państwowym jednostkom organizacyjnym będącym państwowymi osobami prawnymi, który przysługiwał im w poprzednim stanie prawnym, wprowadziła uchylona z dniem 1 stycznia 1998 r. ustawa z 29 września 1990 r. o zmianie ustawy o gospodarce gruntami i wywłaszczaniu nieruchomości ${ }^{55}$, o ile ten ostatni akt prawny mógł być stosowany w zakresie danego stanu faktycznego.

9. Podsumowując, należy stwierdzić, że zarówno trwały zarząd, jak i zarząd ustawowy stanowią istotny element uprawnień właścicielskich. Niekiedy trudno odróżnić te dwie instytucje. Odmienne są jednak źródła ich powstawania i wygaszania, o ile w ogóle można mówić o wygaszeniu zarządu leśnego - należy raczej opowiedzieć się przeciwko takiej możliwości. Z kolei ocena dopuszczalności wygaśnięcia w trybie obowiązujących przepisów prawa zarządu (niekiedy błędnie uznawanego za przekształcony w trwały zarząd), powstałego na podstawie ustawy o gospodarce gruntami i wywłaszczaniu nieruchomości, wymaga ustalenia w szczególności, czy wspomniany akt prawny w ogóle mógł mieć zastosowanie do gruntów objętych decyzją stwierdzającą prawo zarządu (tj. jakie było przeznaczenie gruntu) i czy do tego przypadku miały ewentualnie zastosowanie przepisy art. 2 ust. 1 lub art. 4 uchylonej z dniem 1 stycznia 1998 r. ustawy z 29 września 1990 r. o zmianie ustawy o gospodarce gruntami i wywłaszczaniu nieruchomości.

Jeśli bowiem to te ostatnie regulacje mają zastosowanie, może to wykluczać zastosowanie art. 199 ust. 2 u.g.n., a wówczas nie mogło dojść do przekształcenia zarządu powstałego w czasie obowiązywania ustawy o gospodarce gruntami i wywłaszczaniu nieruchomości w trwały zarząd. Jeśli natomiast nie doszło do wygaszenia zarządu na podstawie ustawy z 1990 r., to należy ustalić, czy powstał trwały zarząd na podstawie art. 199 ust. 2 u.g.n. Wydaje się to wątpliwe.

Oczywiste jest, że zarząd Lasów Państwowych sprawowany na podstawie ustawy o lasach nie podlega wygaszeniu tak jak zarząd trwały. Jedynie bowiem prawo zarządu powstałe w czasie obowiązywania ustawy o gospodarce gruntami i wywłaszczaniu nieruchomości, które uległo przekształceniu w trwały zarząd, mogłoby podlegać wygaszeniu jak trwały zarząd. Należy także wykluczyć równoległe istnienie dwóch rodzajów zarządu: zarządu ustawowego i trwałego; w takim przypadku należałoby rozważyć (choć nie bez wątpliwości), czy nie doszło do wygaśnięcia zarządu wobec zmiany prawa (wejścia w życie ustawy o lasach), która prowadzi do wygaśnięcia

${ }^{55}$ Por. także uchwałę Sądu Najwyższego - Izby Cywilnej z 27 sierpnia 1996 r. III CZP/95/96, Legalis, w której SN wskazał: „Podstawę wykreślenia w księdze wieczystej wpisu o zarządzie i użytkowaniu, przysługujących państwowej osobie prawnej do nieruchomości, odnośnie której ma zastosowanie art. 8 ustawy z dnia 29 września 1990 r. o zmianie ustawy o gospodarce gruntami i wywłaszczaniu nieruchomości (Dz. U. Nr 79, poz. 464 ze zm.), stanowi decyzja kierownika urzędu rejonowego". 
zarządu powstałego wcześniej (art. $162 \S 1$ pkt 1 k.p.a. ${ }^{56}$ ). Co prawda NSA niejednokrotnie uznawał, że właśnie zmiana stanu prawnego może być okolicznością stanowiącą podstawę stwierdzenia wygaśnięcia decyzji z uwagi na bezprzedmiotowośćs7, jednak i to rozwiązanie nie jest dość oczywiste. Uzasadnione byłoby zatem twierdzenie, że wobec wejścia $\mathrm{w}$ życie przepisów ustawy o lasach niemożliwe stało się wykonywanie decyzji regulującej prawo zarządu powstałego wcześniej, gdyż to ustawa o lasach uregulowała „na nowo” prawne warunki zarządu.

\section{BIBLIOGRAFIA}

Bieluk J. (2017), Ograniczenia w obrocie lasami w świetle prawa polskiego i unijnego, w: P. Litwiniuk (red.), Integracja europejska jako determinanta polityki wiejskiej. Aspekty prawne, Warszawa.

Chełchowski A. (2010), Trwały zarząd nieruchomościami publicznymi, Warszawa, Legalis.

Czechowski P. (red.) (2015), Ustawa o gospodarce nieruchomościami. Komentarz, Warszawa, LEX.

Gniewek E. (2001), Kodeks cywilny. Ksiega druga. Własność i inne prawa rzeczowe. Komentarz, Kraków, LEX.

Gudowski J. (red.) (2016), Kodeks cywilny. Komentarz, t. 2: Własność i inne prawa rzeczowe, Warszawa, LEX.

Jaworski J., Prusaczyk A., Tułodziecki A., Wolanin M. (2019), Ustawa o gospodarce nieruchomościami. Komentarz, Warszawa, Legalis.

Jeżyńska B. (1993), Z cywilnoprawnych zagadnień sprzedaży lasów przez osobę fizyczna, „Rejent” nr 8.

Leśkiewicz K. (2019), Prawne aspekty zarządzania lasami Skarbu Państwa, Lublin.

Litwiniuk P. (2017), Ewolucja rozwiazań normatywnych w zakresie gospodarowania nieruchomościami rolnymi Skarbu Państwa, „Studia Iuridica Agraria” t. XV.

Możdżeń-Marcinkowski M. (2003), Agencja Nieruchomości Rolnych, Kraków.

Pańko W. (2016), O prawie własności i jego współczesnych funkcjach, Katowice.

Pessel R. (2010), Nieruchomości Skarbu Państwa, Warszawa.

Radecki W. (2017), Ustawa o lasach. Komentarz, Warszawa.

Szachułowicz J., Krassowska M., Łukaszewska A. (2003), Gospodarka nieruchomościami. Komentarz, Warszawa.

Ziemblicki M.H. (2015), Uwarunkowania prawne nadzoru nad lasami niestanowiacymi własności Skarbu Państwa, „Białostockie Studia Prawnicze” z. 18.

${ }^{56}$ Ustawa z 14 czerwca 1960 r. Kodeks postępowania administracyjnego (t.j. Dz. U. z 2020 r., poz. 256).

57 Wyrok NSA z 18 sierpnia 2017 r., II OSK 2218/16, Legalis. NSA stwierdził: „Bezprzedmiotowość decyzji, o której mowa w art. $162 \S 1$ pkt 1 kpa, wynika z ustania prawnego bytu elementu stosunku materialnoprawnego nawiązanego na jej podstawie, a to z powodu zgaśnięcia podmiotu, zniszczenia lub przekształcenia rzeczy, rezygnacji z uprawnień przez stronę, czy na sutek zmiany stanu faktycznego uniemożliwiającego wykonanie decyzji albo z powodu zmiany w stanie prawnym, ale tylko w przypadku, gdy powoduje ona taki skutek". 


\title{
LEGAL ASPECTS OF THE TERMINATION OF PERMANENT MANAGEMENT VIS A VIS THE STATUTORY MANAGEMENT OF STATE FORESTS
}

\author{
Sum mary
}

The aim of the considerations presented in the article was to determine whether and if so, in what way, the management created with regard to real estate managed by the State Forests during the validity of the Act on land management and real estate expropriation may cease to exist. In the author's opinion, the State Forests' management performed under the provisions of the Forest Act is not subject to termination in the manner that applies to the permanent management of real estate. The question that needs to be addressed and assessed is whether the termination of the management under the Act on land management and real estate expropriation requires a precise determination and, in particular, whether the said legislative act could apply to forest land covered by the decision confirming the right of management. It must also be considered whether the provisions of Article 2.1 or Article 4 of the Act of 29 September 1990 amending the Act on land management and expropriation of real estate should apply in such cases. Had the latter regulations applied, then the management created when the Act on land management and real property expropriation was in force, could not have been transformed into permanent management pursuant to Article 199 clause 2 of the Act on the management of real property.

Keywords: permanent management, forest management, termination of permanent management

\section{LA CESSAZIONE DELL'AMMINISTRAZIONE PERMANENTE E L'AMMINISTRAZIONE LEGALE DELLE FORESTE DEMANIALI: ASPETTI GIURIDICI}

\section{Riassunto}

L'articolo si propone di determinare se e, in caso affermativo, come sia possibile rescindere l'amministrazione istituita ai sensi della legge in materia di gestione dei terreni e espropriazione degli immobili, quando era ancora in vigore, nei confronti dei beni immobili gestiti dall'amministrazione delle Foreste Demaniali. A parere dell'autrice l'amministrazione delle Foreste Demaniali, istituita dalla legge sulle foreste, non è soggetta a cessazione, lo è invece l'amministrazione permanente prevista dalle disposizioni riguardanti la gestione degli immobili. Tuttavia, per valutare se consentire la cessazione dell'amministrazione istituita dalla legge in materia di gestione dei terreni e di espropriazione degli immobili occorre stabilire se il suddetto atto giuridico potesse applicarsi ai terreni forestali, i quali andavano comunque amministrati. Inoltre, è importante determinare se in questa situazione vadano applicate le disposizioni dell'art. 2 comma 1 oppure dell'articolo 4 della legge del 29 settembre 1990, la quale ha modificato la legge in materia di gestione dei terreni e espropriazione degli immobili. Se quest'ultime regolazioni andavano applicate, in tal caso l'amministrazione istituita dalla legge in materia di gestione dei terreni e espropriazione degli immobili, quando era ancora in vigore, non sarebbe potuta diventare permanente ai sensi dell'art. 1999 comma 2 della legge sulla gestione degli immobili.

Parole chiave: amministrazione permanente, amministrazione delle foreste, cessazione dell'amministrazione permanente 